\title{
Penalaran Analogi Siswa SMP Tipe Climber dalam Menyelesaikan Masalah Matematika
}

\author{
Muniroh Novisa ${ }^{1}$, Subanji $^{1}$, Purwanto ${ }^{1}$ \\ ${ }^{1}$ Pendidikan Matematika-Universitas Negeri Malang
}

\begin{tabular}{l}
\hline \hline INFO ARTIKEL \\
\hline Riwayat Artikel: \\
Diterima: 11-07-2019 \\
Disetujui: $14-02-2020$ \\
\hline
\end{tabular}

\section{Kata kunci:}

analogy reasoning; mathematics; adversity quotient; penalaran analogi; matematika:

adversity quotient

\author{
Alamat Korespondensi: \\ Muniroh Novisa \\ Pendidikan Matematika \\ Universitas Negeri Malang \\ Jalan Semarang 5 Malang \\ E-mail: muniroh.1703118@students.um.ac.id
}

\begin{abstract}
Analogy reasoning ability is the ability of students to connect two problems. Students' ability to overcome problems can be seen from Adversity quotient (AQ), one type of AQ is the climber. This study aims to identify the analogy reasoning of climber type students. The instruments used in this study were test questions and interviews. The results of this study in solving the problem of climber type students try hard to identify important information in the problem, determine the problem solving strategy based on similarity relationships to solve the problem between two problems and apply in solving problems to find problem solving.
\end{abstract}

ABSTRAK

\begin{abstract}
Abstrak: Kemampuan penalaran analogi merupakan kemampuan siswa dalam menghubungkan dua masalah. Kemampuan siswa dalam mengatasi masalah dapat dilihat dari Adversity quotient (AQ), salah satu tipe dari AQ adalah climber. Penelitian ini bertujuan untuk mengidentifikasi penalaran analogi siswa tipe climber. Instrumen yang digunakan dalam penelitian ini adalah soal tes dan wawancara. Hasil penelitian ini dalam menyelesaikan masalah siswa tipe climber berusaha keras mengidentifikasi informasi penting dalam masalah, menentukan strategi penyelesaian masalah berdasarkan hubungan kemiripan penyelesaian masalah antara dua masalah, serta menerapkan dalam penyelesaian masalah hingga menemukan penyelesaian masalah.
\end{abstract}

Analogi dapat ditemui dalam berbagai situasi, baik itu dalam menyampaikan pengetahuan, serta penarikan kesimpulan dari beberapa konsep, situasi, atau domain yang berbeda. Analogi merupakan kemiripan antara kejadian berbeda yang membantu dalam penarikan kesimpulan (Vosniadou \& Skopeliti, 2018). Analogi sangat membantu memahami konsep yang bersifat abstrak dan mengasosiasikan ke dalam ide yang baru (Urbanski et al., 2016). Analogi sering digunakan dalam menemukan hubungan antara dua kejadian. Identifikasi dalam menemukan dan menggunakan hubungan antara dua kejadian yang mirip ini disebut dengan penalaran analogi (Gentner \& Smith, 2012). Setiap anak pada dasarnya memiliki penalaran analogi karena struktur neural dari penalaran analogi telah ada pada manusia sejak umur enam tahun (Vendetti, Matlen, Richland, \& Bunge, 2015). Penalaran analogi seseorang berkembang seiring dengan bertambahnya kemampuan dalam relasi dan berkembangnya kemampuan dalam melihat hubungan (Richland, Morrison, \& Holyoak, 2006).

Penalaran analogi adalah kemampuan bernalar dalam menghubungkan dua masalah, yaitu masalah sumber dan masalah target (masalah yang jarang ditemui). Masalah sumber adalah masalah yang sering dijumpai sehingga lebih mudah diselesaikan sedangkan masalah target adalah masalah yang jarang dijumpai sehingga agak sulit untuk diselesaikan, walaupun tingkat masalah sumber dan masalah target berbeda, namun kedua masalah ini memiliki kemiripan. Kemampuan siswa dalam menemukan kemiripan serta menggunakannya dalam setiap masalah yang diberikan berpengaruh pada kemampuan siswa dalam menyelesaikan masalah. Penalaran analogi, khususnya pemetaan lintas domain, dianggap sebagai mekanisme penting untuk restrukturisasi konseptual (Vamvakoussi, 2017). Penting bagi siswa memiliki penalaran analogi untuk membantu siswa dalam menyelesaikan masalah yang lebih sulit atau jarang mereka jumpai dengan melihat kemiripan pada masalah yang sering mereka jumpai baik itu dari prosedur penyelesaian, konsep, dan pola-pola. Menganalisis analogi dapat membantu dalam menyelesaikan masalah yang memiliki struktur analogi (Vendetti, Wu, \& Holyoak, 2014).

Penalaran analogi menjadi salah satu faktor yang memengaruhi kemampuan siswa dalam memecahkan masalah (Loc \& Uyen, 2016). Siswa yang memiliki kemampuan analogi yang baik dapat lebih mudah dalam memecahkan masalah ketika dihadapkan pada permasalahan yang baru. Penalaran analogi terbagi menjadi tiga tipe penalaran dengan analogi klasik, analogi masalah, dan analogi pedagogi. Analogi klasik memiliki bentuk A:B:C:D yang mana C dan D saling berhubungan begitu pula dengan A dan B. Analogi masalah adalah masalah yang memiliki kemiripan dimana satu masalah yang telah diketahui dapat 
membantu memecahkan masalah yang baru dengan mengidentifikasi kemiripan diantara kedua masalah. Analogi pedagogi yang digunakan untuk memberikan representasi konkret dari ide-ide abstrak (English, 2004).

Penalaran analogi memiliki empat komponen utama menurut (Sternberg, 1977) adalah pengodean (encoding), menduga (inferring), pemetaan (mapping), penerapan (applying). Adapun menurut (Ruppert, 2013) empat komponen penalaran analogi adalah penstrukturan (structuring), pemetaan (mapping), penerapan (applying), dan verifikasi (verifying). Pada penelitian ini akan menggunakan empat komponen penalaran analogi Sternberg yang mana siswa yang mampu melihat atau menemukan kata kunci dalam masalah yang diberikan dapat dikatakan mampu melakukan pengodean. Siswa yang mampu menduga strategi pemecahan masalah target yang sesuai berdasarkan masalah sumber yang diberikan yang berguna sebagai pengetahuan awal siswa dapat dikatakan sebagai mampu melakukan inferring, siswa yang mampu menemukan hubungan antara masalah sumber dan masalah target dapat dikatakan mampu melakukkan mapping, siswa yang mampu menyelesaikan masalah target dengan cara yang sama dengan menyelesaikan masalah sumber dapat dikatakan mampu melakukan applying. Dalam Penalaran analogi perlu dipertimbangkan (Amir-Mofidi, 2012) (1) mengusahakan untuk menemukan masalah yang memiliki kemiripan, tetapi berbeda dari masalah aslinya; (2) kemampuan siswa dalam menyelesaikan masalah; (3) membuat hubungan antara dua kasus dengan tingkat kesulitan yang berbeda dengan contoh analog; (4) memisahkan hasil analogi dari langkahlangkah pemecahan masalah lainnya, seperti menghasilkan kasus-kasus sulit, memecahkan solusi atau metode berpikir dalam bagian tersendiri, dan menganalisis masalah dalam hal prinsip teoretis. Penting bagi siswa untuk menemukan pola dari masalah matematika sehingga ketika siswa menemukan soal yang jarang ditemuinya siswa dapat menemukan kemiripan pada soal yang sering ditemuinya sehingga siswa dapat menggeneralisasikan untuk menyelesaikan permasalahan yang jarang ditemuinya tersebut. Dalam menghadapi masalah yang jarang ditemuinya siswa menghadapinya dengan respons yang berbeda-beda.

Kemampuan siswa dalam mengatasi masalah dapat dilihat dari Adversity quotient (AQ), Stoltz (2004) mengategorikan kemampuan dalam menghadapi masalah menjadi tiga kategori, yaitu climber, camper, dan quitter. Climber adalah siswa yang ketika dihadapkan dengan masalah berusaha semaksimal mungkin untuk menyelesaikan masalah yang dihadapinya, walaupun ketika dalam prosesnya bertemu dengan berbagai macam rintangan. Campers adalah siswa yang ketika dihadapkan dengan masalah akan mencoba untuk menyelesaikan masalah yang dihadapinya, namun ketika dalam prosesnya mendapatkan kesulitan atau rintangan maka siswa tersebut memilih untuk berhenti, siswa dengan kategori camper juga dapat dikatakan sebagai siswa yang cepat puas dengan hasil yang telah dicapainya sehingga tidak berusaha semaksimal mungkin dalam menyelesaikan masalah yang dihadapinya. Quitter adalah siswa yang ketika dihadapkan dengan masalah memilih untuk menyerah dan tidak memiliki kemauan untuk menyelesaikan masalah yang dihadapinya. Dalam penelitian yang dilaksanakan oleh Leonard dijelaskan bahwa AQ memiliki pengaruh terhadap proses berpikir siswa dalam menyelesaikan masalah (Leonard \& Amanah, 2014). Dalam penelitian ini membahas tentang penalaran analogi siswa climber dalam menyelesaikan masalah matematika SMP. Dipilihnya siswa climber dalam penelitian ini karena siswa climber dapat memenuhi setiap tahapan penalaran analogi dibandingkan siswa campers dan siswa quitter.

\section{METODE}

Penelitian ini dilaksanakan pada kelas VIIIA di sekolah MTsN 6 Banjar dikarenakan ditemukannya siswa yang bernalar analogi dalam menyelesaikan masalah. Pada penelitian ini akan mendeskripsikan tentang penalaran analogi siswa tipe climber dalam menyelesaikan masalah matematika SMP. Instrumen yang digunakan dalam penelitian ini berupa tes masalah matematika, angket ARP, dan wawancara. Tes masalah matematika yang yang diberikan untuk masalah sumber dibuat berkaitan dengan materi teori bilangan dan masalah target diadaptasi dari soal matematika PISA pada tahun 2012. Angket ARP (Adversity Response Profile) adalah angket yang dibuat Stoltz untuk mengategorikan AQ seseorang. Angket ARP modifikasi telah disesuaikan dengan pengalaman siswa SMP. Angket ARP dibutuhkan dalam penelitian ini untuk mengetahui tipe-tipe AQ siswa. Subjek yang dipilih pada penelitian dipilih berdasarkan angket ARP dan hasil tes masalah matematika. Wawancara diperlukan dalam penelitian ini guna mengetahui lebih dalam tentang proses penalaran analogi subjek. Dari hasil angket ARP dan tes masalah matematika yang diberikan kepada siswa dipilih dua orang siswa yang memenuhi kriteria yaitu memiliki AQ dengan tipe climber dan menyelesaikan tes masalah matematika menggunakan penalaran analogi.

\section{HASIL}

\section{Penalaran Analogi Subjek tipe Climber 1 (S1)}

S1 menggunakan penalaran analogi dalam menyelesaikan masalah target. Dalam menyelesaikan masalah S1 berusaha memahami masalah yang diberikan kemudian mengidentifikasi informasi penting yang diperoleh dalam masalah. Pada gambar 2 terlihat bahwa S1 mengidentifikasi informasi penting yang diperoleh dalam masalah sumber dan masalah target. Sehingga S1 telah melakukan tahap encoding dalam menyelesaikan masalah. Berikut merupakan hasil wawancara dengan S1:

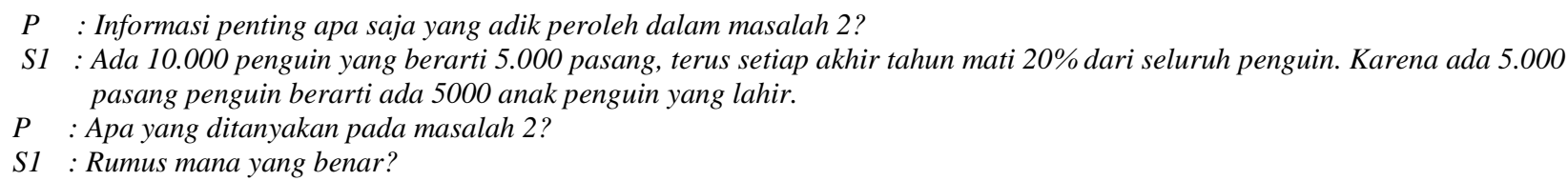




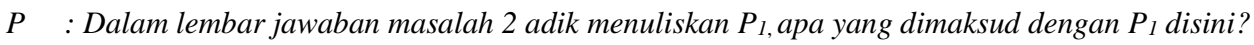

$S 1$ : Oh, $P_{1}$ disini maksudnya penguin pada tahun pertama kak, $P_{2}$ ini penguin pada tahun kedua, terus $P_{7}$ ini penguin pada tahun ketujuh.

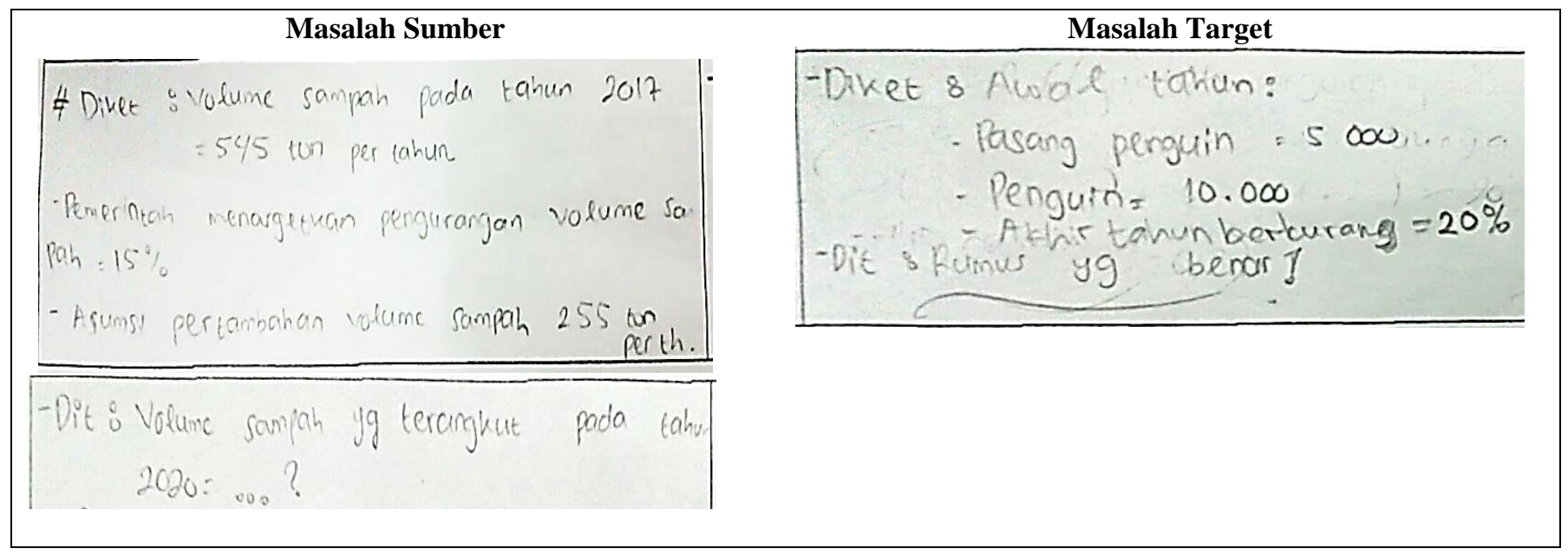

\section{Gambar 2. Lembar Jawaban S1 Tahap Encoding}

Dari wawancara terlihat bahwa S1 telah masuk pada tahap Encoding karena mampu mengidentifikasi informasi penting yang diperoleh dalam masalah II, memahami apa yang ditanyakan pada masalah II, S1 juga membuat memisalkan jumlah penguin. Pada tahap Inferring S1 membuat dugaan kemiripan struktur penyelesaian untuk masalah sumber dan masalah target berikut. Pada masalah sumber untuk menentukan volume sampah yang terangkut pada tahun 2020, S1 menentukan volume sampah yang terangkut pada tahun 2018 dengan menentukan menentukan hasil dari $(545+255)-(545+255) \times \frac{15}{100}$ yang diperoleh volume sampah yang terangkut pada tahun 2018 adalah 680. Pada masalah target, S1 menduga bahwa untuk menemukan rumus jumlah penguin pada tahun ketujuh, S1 perlu mengetahui rumus yang tepat untuk menentukan jumlah penguin pada tahun pertama. Pada lembar jawaban S1 menuliskan $P_{1}=(10.000+5.000)-(10.000+5.000) \times 20 \%$, untuk menentukan rumus jumlah penguin pada tahun pertama.

Berikut merupakan hasil wawancara dengan S1:

$P \quad$ : Bagaimana adik menyelesaikan masalah 2?

S1 : 10.000 penguin berarti ada 5.000 anak penguin terus ditambahkan 10.000 dan 5.000 nya diakhir tahun berkurang $20 \%$ dari seluruh jumlah penguin. Sama seperti masalah 1. Terus yang dicarikan rumusnya berarti rumusnya seperti ini (menunjuk jawaban nomor 2 pada lembar jawaban) untuk akhir tahun pertama. Terus untuk akhir tahun kedua 10.000 (1,5 $\times 0,8)$ ditambahkan dengan $\frac{1}{2}(10.000(1,5 \times 0,8))$ dikurang $20 \%$ nya.

S1 telah masuk pada tahap Inferring karena terlihat dari lembar jawaban masalah II dan wawancara bahwa S1 telah menyimpulkan bahwa terdapat kemiripan dalam struktur penyelesaian masalah antara masalah sumber dan masalah target. Untuk menentukan rumus jumlah penguin pada tahun ketujuh S1 menerapkan strategi penyelesaian yang sama antara masalah sumber dan masalah target.

Pada tahap Mapping, S1 pada masalah sumber menyelesaikan masalah dengan membuat untuk menentukan volume sampah yang terangkut pada tahun 2018, S1 menerapkan pola tersebut untuk menentukan volume yang terangkut pada tahun 2019. S1 mensubtitusikan volume sampah yang terangkut pada tahun 2018 ke dalam pola $(680+255)-(680+255) \times \frac{15}{100}$ diperoleh volume sampah yang terangkut pada tahun 2019 adalah 794,75 . Kemudian untuk menentukan volume sampah yang terangkut pada tahun 2020 dengan mensubtitusikan volume sampah yang terangkut pada tahun 2019 dalam rumus $(794,75+$ $255)-(794,75+255) \times \frac{15}{100}$ diperoleh volume sampah yang terangkut pada tahun 2020 adalah 892,2875 ton. Untuk menyelesaikan masalah target S1 menentukan rumus jumlah penguin pada tahun pertama kemudian menentukan rumus jumlah penguin pada tahun kedua untuk menentukan rumus jumlah penguin pada tahun ketujuh. Oleh karena itu, S1 telah masuk pada tahap Mapping, S1 telah memetakan struktur penyelesaian masalah sumber ke struktur penyelesaian masalah target.

Pada tahap Applying S1 membuat kesimpulan bahwa strategi penyelesaian masalah sumber dan masalah target sama maka S1 menyelesaikan masalah target berdasarkan pada simpulan bahwa untuk menentukan rumus jumlah penguin pada tahun ketujuh S1 perlu menentukan rumus jumlah penguin pada tahun pertama kemudian rumus jumlah penguin pada tahun kedua. Ini terlihat pada lembar jawaban masalah target S1. S1 juga menyimpulkan bahwa jika rumus jumlah pada tahun pertama adalah 
$10.000 \times 1,5 \times 0,8$, dan untuk tahun kedua adalah $10.000 \times 1,5^{2} \times 0,8^{2}$, maka untuk tahun ketujuh $10.000 \times 1,5^{7} \times 0,8^{7} . \mathrm{S} 1$ dalam menyelesaikan masalah berusaha menyelesaikan masalah dengan benar. S1 mengalami beberapa kendala dalam membentuk rumus jumlah penguin, namun tetap berusaha menyelesaikan masalah yang diberikan.

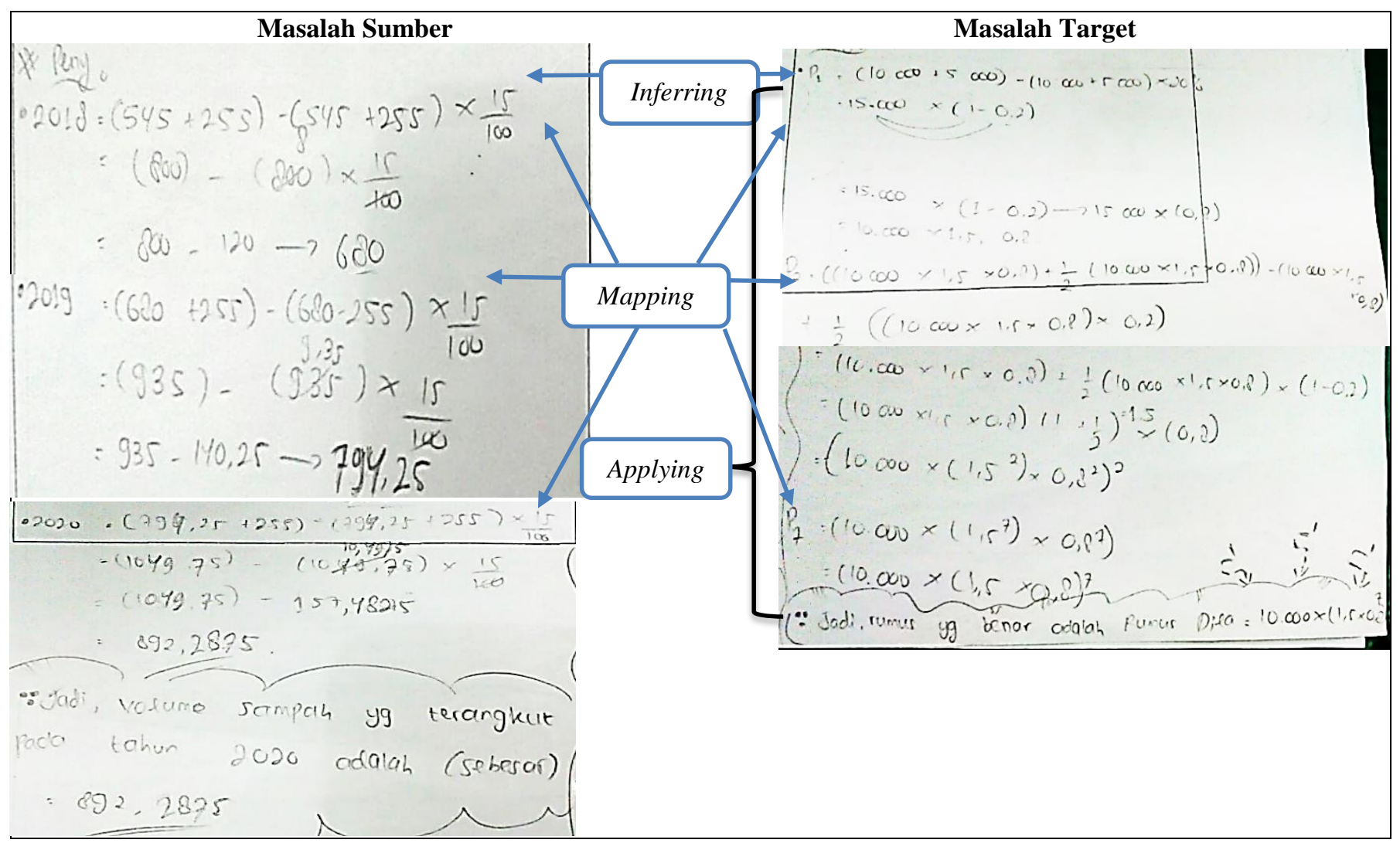

Gambar 3. Lembar Jawaban S1 Pada Tahap Inferring, Mapping, dan Applying

\section{Penalaran Analogi Subjek tipe Climbers 2 (S2)}

Dalam menyelesaikan masalah sumber dan masalah target, S2 berusaha memahami masalah, mengidenfikasi informasi penting untuk menyelesaikan masalah, kemudian menuliskan semua informasi penting yang diperoleh dalam masalah sumber. Berikut merupakan informasi penting yang diperoleh S2 pada masalah sumber:

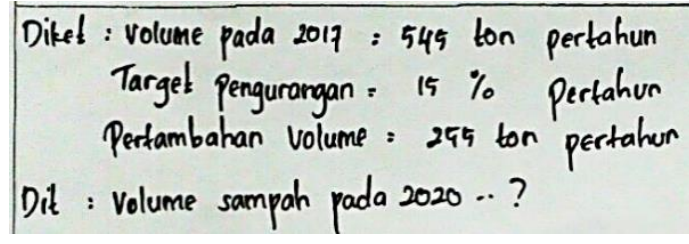

Gambar 4. Lembar Jawaban Masalah Sumber S2

Dalam menyelesaikan masalah target, pada tahap Encoding S2 berusaha memahami masalah, mengidentifikasi informasi penting yang diperoleh dalam masalah target untuk menyelesaikan masalah. S2 tidak menuliskan informasi penting yang diperolehnya pada lembar jawaban, namun dalam wawancara S2 mampu menjelaskan informasi penting apa saja yang S2 peroleh dalam masalah target.

P: Informasi penting apa saja yang kamu peroleh dalam masalah 2?

S2: Pada awal tahun terdapat 10.000 pinguin. berarti ada 5.000 pasang penguin yang melahirkan 5.000 anak penguin. Pada akhir tahun akan mati $20 \%$ penguin.

P: Mengapa tidak dituliskan didalam lembar jawaban masalah 2?

S2: Saya mengerjakan soal nomor 2 ini, setelah membaca soal langsung berpikir ini mirip-mirip sama soal nomor 1 kak jadi saya langsung menulis bentuk seperti ini kak (menunjuk jawaban masalah 2 pada lembar jawaban), malah lupa menuliskan diketahuinya. 
Dari informasi penting yang dijelaskan pada wawancara terlihat bahwa S2 dapat mengidentifikasi informasi penting dalam masalah target sehingga S2 mampu melakukan tahap Encoding. Pada tahap Inffering, dalam menyelesaikan masalah sumber, untuk menentukan volume sampah yang terangkut pada tahun 2020, S2 menentukan volume sampah yang terangkut pada tahun 2018 terlebih dahulu dengan membentuk pola $(545+255)-(545+255) \times \frac{15}{100}$ sehingga diperoleh volume sampah yang terangkut pada tahun 2018 adalah 680.

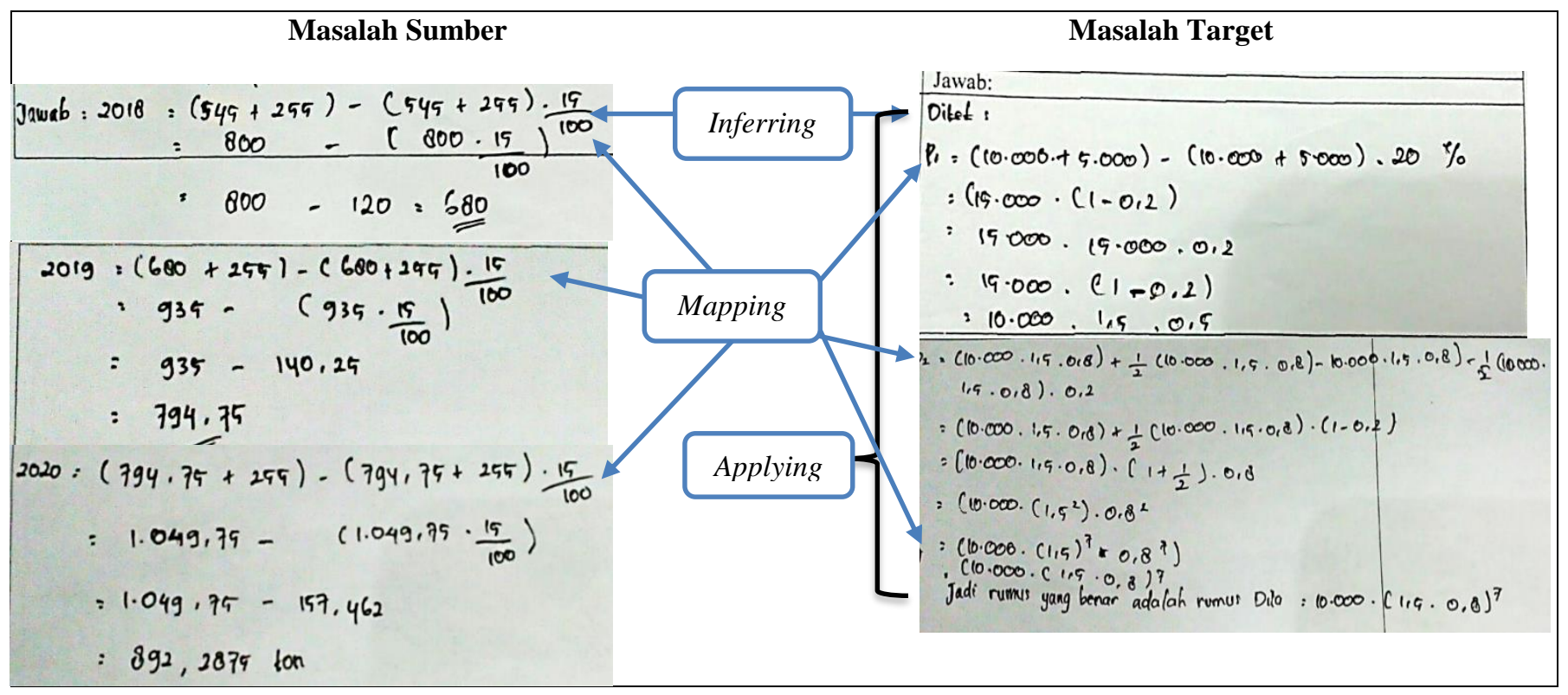

Gambar 5. Lembar Jawaban S2 Pada Tahap Inferring, Mapping dan Applying

Untuk menyelesaikan masalah target, Pada tahap Inffering, S2 pada lembar jawaban menuliskan $P_{1}=(10.000+$ $5.000)-(10.000+5.000) \times 20 \%$. Terlihat bahwa S2 menuliskan pola $P_{1}$ berdasarkan pada dugaan bahwa terdapat kemiripan struktur penyelesaian antara masalah sumber dan masalah target. Ini terlihat juga dalam hasil wawancara S2 yang menyatakan dugaan bahwa terdapat kemiripan pada struktur penyelesaian kedua masalah pada tahap ini S2 telah masuk pada tahap Inferring.

P: Bagaimana adik menyelesaikan masalah 2 ini?

S2: Ini 10.000 pinguin terus ditambah 5.000 anak pinguin. Kemudian dikurang 10.000 ditambah 5.000 dikali 20\%. Ini jadinya sama saja dengan 15.000 dikurang 15.000 dikali 0,2. 0,2 ini dari 20 dibagi 100 (menunjuk jawaban nomor 2 pada lembar jawaban) Jadi rumusnya ini. Lalu untuk menentukan rumus penguin pada tahun kedua sama seperti soal nomor 1 kak.

P: Bagian mana yang sama nomor 1?

S2: Nomor 1 mengerjakannya dengan menghitung volume sampah tahun 2018 dulu, terus tahun 2019, baru tahun 2020. Jadi bertahap tiap tahunnya. Nah untuk soal nomor 2 begitu juga jadi dicari dulu rumus untuk tahun pertama. Baru cari lagi tahun kedua.

Pada tahap Mapping, S2 dalam menyelesaikan masalah sumber untuk menentukan volume sampah pada tahun 2020 , S2 perlu menentukan volume sampah tahun 2018, setelah menemukan volume sampah yang terangkut pada tahun 2018 selanjutnya S2 menentukan volume sampah terangkut pada tahun 2019 dengan mensubtitusikan volume sampah yang terangkut pada tahun 2018 dalam pola yaitu $(680+255)-(680+255) \times \frac{15}{100}$ diperoleh volume sampah yang terangkut pada tahun 2019 adalah 794,75.

Kemudian untuk menentukan volume sampah yang terangkut pada tahun 2020 dengan mensubtitusikan volume sampah yang terangkut pada tahun 2019 dalam pola $(794,75+255)-(794,75+255) \times \frac{15}{100}$ diperoleh volume sampah yang terangkut pada tahun 2020 adalah 892,29 ton. Untuk menyelesaikan masalah target, S2 menyimpulkan terdapat hubungan antara penyelesaian masalah sumber dengan masalah target. Untuk menentukan rumusan banyak penguin pada tahun kedua $\mathrm{S} 2$ menulis $\quad P_{2}=10.000(1,5 \times 0,8)+\frac{1}{2} 10.000(1,5 \times 0,8)-\left(10.000(1,5 \times 0,8)+\frac{1}{2} 10.000(1,5 \times 0,8) \times 0 \quad \mathrm{~S} 2\right.$ menghubungkan cara menentukan rumus banyak penguin pada tahun selanjutnya dengan cara menentukan berat sampah pada tahun 2019 pada masalah sumber. Ini terlihat juga pada hasil wwawancara berikut: 
P: Bagaimana adik menyelesaikan masalah 2?

S2: Untuk tahun ke 2, jumlah penguin dari tahun pertama ini (menunjuk ke jawaban masalah 2 pada lembar jawaban) ditambah jumlah anak penguin pada tahun pertama yaitu setengahnya dari jumlah penguin pada tahun pertama. Dikurangkan dengan jumlah penguin dari tahun pertama ditambah jumlah anak penguin pada tahun kedua dikali 0,2

Pada tahap Applying, S2 mampu menyelesaikan masalah target menggunakan struktur penyelesaian yang sama dengan masalah sumber. Berdasarkan pada kesimpulan hubungan penyelesaian masalah sumber dan masalah target S2 menemukan rumus jumlah penguin pada akhir tahun kedua dan untuk rumus menentukan rumus jumlah penguin pada akhir tahun ketujuh $\mathrm{S} 2$ menyimpulkan bahwa jika $P_{2}=10.000(1,5 \times 0,8)^{2}$ maka jumlah pinguin pada tahun ketujuh adalah $P_{7}=10.000(1,5 \times 0,8)^{7}$.

Dalam menyelesaikan masalah sumber dan masalah target siswa tipe climber berusaha keras untuk menyelesaikan dengan benar. Dalam menentukan rumus jumlah penguin pada masalah target siswa tipe climber berusaha menentukan rumus tepat dengan menentukan terlebih dahulu rumus jumlah penguin pada tahun pertama. Kemudian menentukan rumus jumlah penguin pada tahun kedua, setelah itu menyimpulkan rumus jumlah penguin pada tahun ketujuh. Siswa tipe climber berusaha menyelesaikan masalah sampai selesai. Bahkan, siswa tipe climber berusaha bertanya kepada peneliti, namun pada akhirnya siswa tipe climber menemukan sendiri penyelesaian masalahnya. Ketika menentukan rumus jumlah penguin siswa tipe climber mengalami kesulitan dalam menentukan membentuk rumus jumlah penguin pada tahun pertama, siswa tipe climber berusaha menyelesaikan masalah dengan benar bahkan bertanya kepada peneliti, dan pada akhirnya siswa tipe climber menemukan sendiri penyelesaian masalah target. Hal ini sesuai dengan teori yang dikemukaan oleh Stoltz (2000) yang menyatakan bahwa orang tipe climber merupakan orang yang selalu berusaha menghadapi semua rintangan yang dihadapkan padanya dan selalu berusaha mencapai kesuksesan.

\section{SIMPULAN}

Berdasarkan hasil dari penelitian ini dapat disimpulkan bahwa siswa tipe climber dapat melakukan keempat tahapan panalaran analogi, yaitu tahap Encoding, Inferring, Mapping, dan Applying. Dalam menyelesaikan masalah sumber siswa tipe climber berusaha memahami masalah yang diberikan, kemudian menentukan informasi penting apa saja yang diperlukan untuk menyelesaikan masalah sumber, Kemudian siswa tipe climber menentukan strategi penyelesaian masalah sumber adalah menggunakan pola bilangan. Karena sudah memahami materi pola bilangan siswa tipe climber tidak mengalami kesulitan dalam menentukan penyelesaian masalah sumber. Dalam menyelesaikan masalah target siswa tipe climber pada tahap encoding membaca masalah target kemudian berusaha memahami masalah, dan mengidentifikasi informasi penting yang diperoleh dalam masalah target. Siswa tipe climber pertama menuliskan informasi penting yang terdapat dalam masalah target. Untuk siswa tipe climber kedua tidak menuliskan informasi penting yang terdapat dalam masalah target namun dapat menjelaskan secara lisan. Dalam menentukan strategi penyelesaian masalah target siswa tipe climber membuat dugaan adanya kemiripan struktur penyelesaian masalah target dengan masalah sumber sehingga siswa tipe climber telah memenuhi tahap inferring.

Pada tahap mapping, siswa tipe climber berdasarkan pada dugaan kemiripan struktur penyelesaian masalah, menghubungkan struktur penyelesaian masalah sumber dan masalah target untuk memastikan bahwa struktur penyelesaian masalah sumber dapat diterapkan pada penyelesaian masalah target. Pada tahap applying siswa tipe climber, menerapkan struktur penyelesaian masalah sumber pada penyelesaian masalah target berdasarkan dugaan dan hubungan kemiripan struktur penyelesaian masalah sumber dan masalah target. Pada tahap applying, siswa tipe climber awalnya mengalami kesulitan dalam membuat rumus jumlah penguin, siswa tipe climber tetap berusaha menentukan rumus jumlah penguin yang tepat. Terlihat saat mengerjakan ketika mengalami kesulitan siswa tipe climber berusaha bertanya untuk menyelesaikan masalah target dengan benar. Penelitian ini hanya melibatkan dua siswa tipe climber sehingga perlu dilakukan penelitian lebih lanjut tentang penalaran analogi siswa tipe climber dalam menyelesaikan masalah matematika lebih dari dua subjek untuk melihat konsistensi dalam hasil penelitian.

\section{DAFTAR RUJUKAN}

Amir-Mofidi, S., Amiripour, P., \& Bijan-zadeh, M. H. (2012). Instruction of Mathematical Concepts Through Analogical Reasoning Skills. Indian Journal of Science and Technology, 5(6), 2916-2922.

Gentner, D., \& Smith, L. (2012). Analogical Reasoning. In Encyclopedia of Human Behavior (2nd ed., Vol. 1). https://doi.org/10.1016/B978-0-12-375000-6.00022-7

Leonard, \& Amanah, N. (2014). Pengaruh Adversity Quotient (AQ) dan Kemampuan Berpikir Kritis terhadap Prestasi Belajar Matematika. Perspektif Ilmu Pendidikan, 28(1), 55-64.

Loc, N. P., \& Uyen, B. P. (2016). Students' Errors In Solving Undefined Problem In Analytic Geometry in Space: A Case Study Based on Analogical Reasoning. Asian Journal of Management Sciences \& Education, 5(25), $14-18$.

Richland, L. E., Morrison, R. G., \& Holyoak, K. J. (2006). Children's Development of Analogical Reasoning : Insights from Scene Analogy Problems. 94, 249-273. https://doi.org/10.1016/j.jecp.2006.02.002

Ruppert, M. (2013). Ways of Analogical Reasoning - Thought Processes In An Example Based Learning Environment. Proceedings of the Eigth Congress of the European Society of Research in Mathematics Education, 226-235. Antalaya: Ankara: Middle East Technical University. 
Urbanski, M., Bre, M., Bendetowicz, D., Schotten, M. T. De, Foulon, C., Rosso, C., ... Pradat-diehl, P. (2016). Reasoning by analogy requires the left frontal pole : lesion-deficit mapping and clinical implications. https://doi.org/10.1093/brain/aww072

Vamvakoussi, X. (2017). Using analogies to facilitate conceptual change in mathematics learning. ZDM Mathematics Education, O(0), 0. https://doi.org/10.1007/s11858-017-0857-5

Vendetti, M. S., Matlen, B. J., Richland, L. E., \& Bunge, S. A. (2015). Analogical Reasoning in the Classroom : Insights From Cognitive Science. 9(2), 100-106.

Vendetti, M. S., Wu, A., \& Holyoak, K. J. (2014). Far-Out Thinking: Generating Solutions to Distant Analogies Promotes Relational Thinking. Psychological Science, 25(4), 928-933. https://doi.org/10.1177/0956797613518079

Vosniadou, S., \& Skopeliti, I. (2018). Evaluating the Effects of Analogy Enriched text on the Learning of Science: The Importance of Learning Indexes. Journal of Research in Science Teaching, (August), 1-33.

https://doi.org/10.1002/tea.21523 